Kaipia, R. (2007), The effects of delivery speed on supply chain planning, International Journal of Logistics: Research \& Applications, forthcoming.

(C) 2007 by author and (C) 2007 Taylor \& Francis

Preprinted with permission.

This is a preprint of an article whose final and definitive form will be published in the International Journal of Logistics: Research \& Applications. International Journal of Logistics: Research \& Applications is available online at http://www.informaworld.com.

http://www.informaworld.com/openurl?genre=journal\&issn=1469-848X 


\title{
The effects of delivery speed on supply chain planning
}

\author{
Riikka Kaipia *) \\ Department of Industrial Engineering and Management, Helsinki University of \\ Technology, Espoo, Finland
}

(Received September 2006; final version received 6 September 2007)

\begin{abstract}
Supply chain planning in manufacturing companies is approached in this paper through empirical case-study research. The target was to chart how different types of manufacturing companies are specifying their future volumes and to identify the type of collaborative planning they are implementing with customers and suppliers. Based on interview study results, a framework is presented to explain how flexibility is gained in the supply chain and how flexibility sources are connected to planning. Two main supply chain planning approaches can be identified: forecast-focused and orderfocused planning. The chosen planning approach is explained less according to the production master-scheduling approaches and more according to the delivery speed requirement.
\end{abstract}

Keywords: supply chain planning, case study, flexibility, manufacturing companies

\section{Introduction}

Supply chain planning is the process that captures information on market demand and inventories, and combines it with supply capabilities and constraints to develop a plan for future volumes. It considers the complete supply chain, from raw material procurement to the distribution of finished products to customers, and targets increasing customer value and improving supply chain performance and cost efficiency (Stadtler, 2005; Hoover et al., 2001; Gupta and Maranas, 2003). Supply chain planning is a hierarchical process that includes several phases and levels (Stadtler, 2005).

However, many companies lack knowledge concerning supply chain planning across company borders (Kumar, 2004). The planning processes in companies typically include multiple phases and may be complex and fragmented. The steps in the process cause delays because they may take place independently, at different time intervals, and with varying planning horizons (Kreipl and Pinedo, 2004). Considering the resources required in planning, few companies have departments dedicated to carrying out end-to-end supply chain planning. Instead, companies rely on detached forecasters, procurement planners and production planners (Makatsoris and Chang, 2004). Typically, the planning process is a mixture of automated and manual processes. The decisions that are taken concern different product hierarchy levels, which increase the variability of the total process (Croom et al., 2000).

The lack of integrated planning processes is a serious shortcoming, because it leads to many supply chain inefficiencies. Typically, these include high safety stocks,

1

* Email: riikka.kaipia@tkk.fi 
difficulties in managing seasonal demand patterns, insufficient demand forecasting, long planning horizons, and the inability to capture supply constraints concerning capacity or materials availability (Kumar, 2004). Additionally, there can be stockouts, dissatisfied customers and poor financial performance (Jordan, 2003). Problems in matching demand and supply may lead to excessive levels of inventory created by unpredictable demand and difficulties in forecasting accurately.

The planning function is necessary for three primary reasons. First, resources are limited in production, transportation, capitalisation, and stocks, which, in turn, influence the need for, and use of, capabilities, time, funds, and space. Manufacturing companies may have to choose how to allocate capacity between products if several products are sharing the same production resources. Similarly, decisions as to how to allocate products for customers when demand exceeds supply need to be made. The second reason is that lead times can be lengthy in production or purchasing, and therefore customer needs can not be satisfied immediately. Third, planning is needed to manage the uncertainty that exists in all supply chains. One primary reason for uncertainties relates to rapid changes in the marketplace. Planning complexity grows when planning has to manage short product lifecycles and growing demand for shorter lead times (Vitasek et al., 2003).

The purpose of this study is to investigate how six Finnish manufacturing companies are planning their future operations. The focus is on mid-term operative planning, which looks for the most efficient way to fulfil demand over a medium-term planning horizon. The aim is to study their planning processes and find situational factors that explain the planning approach used. In addition, the sharing and use of information is studied. In particular, the connection between flexibility and supply chain planning is explored.

This paper starts with a literature review that investigates different approaches to managing uncertainty and ways to provide flexibility in supply chains. The research methodology used is then described. Next, the case study results are presented. The framework of flexibility sources and planning integration based on the case results is explained in the subsequent section. Finally, results are discussed, conclusions are presented, and further research is proposed.

\section{Literature review}

\subsection{Different approaches to uncertainty}

Some degree of uncertainty exists in every business organisation. Supply chain uncertainty is related to demand, supply, processes or decision-making (Mason-Jones and Towill, 1998; Van der Vorst et al., 2002). Solutions to handle the issue have been suggested from a variety of viewpoints. An important viewpoint is that the best way to cope with supply chain uncertainty is to reduce uncertainty at its source (Towill et al., 2002), which is shown to be a productive approach in empirical studies (Childerhouse and Towill, 2004). Lee (2002) focuses on managing the supply and demand uncertainty and selecting supply chain strategies according to these. Another 
approach is to focus on manufacturing planning. Vollman et al. (1997) emphasise the selection of production modes as a way of responding to uncertainty.

One way to reduce supply chain uncertainty is to capture more information from the material flow and information flow in various parts of the supply chain, as well as from the market (Mason-Jones and Towill, 1998). The benefits of information sharing to supply chain performance are widely agreed in multiple analytical researches (a recent review of the literature is presented by Byrne and Heavey, 2006). However, the benefits from fast and accurate capturing of demand information are affected by the demand type and supply chain characteristics; consequently, this is not always the most productive way of improving supply chain performance (De Treville et al., 2004).

To benefit from incremental visibility, supply chains have to react to significant changes within an appropriate period to ensure their competitiveness. One important indicator of the ability to react is the planning cycle time, i.e. the time between the beginnings of two subsequent planning cycles. Long planning cycles prevent the plan from taking into account the short-term changes in the environment. Especially at the end of a planning cycle, the plan may no longer fit the current situation. When defining an appropriate planning cycle, the aggregation level of a planning process, planning horizon and planning effort should be considered. For example, the frequency of detailed scheduling should be higher than, for example, capacity planning (Vonderembse and White, 1988; Kreipl and Pinedo, 2004).

The impact of improving planning and planning frequency is based on the notion that the greater the uncertainty, the greater the frequency of revised planning and the increased resources used in planning (Galbraith, 1977). At some point, the decision maker is overloaded by information and it becomes profitable to invest in more efficient communication and information systems. Another approach is to employ lateral decision processes, which cut across the lines of authority. This moves the level of decision making down to where the information exists, rather than bringing the information to the points of decision.

\subsection{Supply chain flexibility}

The planning approaches to creating flexibility are shown in Table 1, grouped according to the flexibility source. Three of the approaches can be characterized as buffer-oriented, where buffering may concern time, capacity or inventories. Zsidisin and Ellram (2003) also treat the use of multiple supplying sources as one buffering form. 
Table 1. Approaches to provide flexibility in supply chains.

\begin{tabular}{|l|l|l|l|}
\hline & Solution & Description & References \\
\hline $\begin{array}{l}\text { Buffer-based } \\
\text { strategies }\end{array}$ & Inventory buffer & $\begin{array}{l}\text { To upkeep inventory to meet } \\
\text { forecast demand, which varies } \\
\text { acc. to time and quantity }\end{array}$ & $\begin{array}{l}\text { Vollman et al., 1997; } \\
\text { Vonderembse and } \\
\text { White, 1988 }\end{array}$ \\
\cline { 2 - 4 } & Capacity buffer & $\begin{array}{l}\text { To upkeep additional capacity } \\
\text { (slack) in the form of production } \\
\text { capacity or workforce; must be } \\
\text { defined in terms of how easy } \\
\text { capacity change should be }\end{array}$ & $\begin{array}{l}\text { Galbraith, 1977; } \\
\text { Vonderembse and } \\
\text { White, 1988 }\end{array}$ \\
\cline { 2 - 5 } & Time buffer & $\begin{array}{l}\text { Long delivery time to allow } \\
\text { production or assembly to } \\
\text { order, used for products with a } \\
\text { large number of possible } \\
\text { configurations. Slack time } \\
\text { included in scheduled time. }\end{array}$ & Vollman et al., 1997; \\
Galbraith, 1977 \\
\hline $\begin{array}{l}\text { Managing } \\
\text { supply risks }\end{array}$ & $\begin{array}{l}\text { Addressing } \\
\text { supplier } \\
\text { processes }\end{array}$ & $\begin{array}{l}\text { Contracting, cooperation, } \\
\text { guaranteeing access to scarce } \\
\text { raw materials; using multiple } \\
\text { supplying sources; devising or } \\
\text { negotiating the environment }\end{array}$ & 2003; Galbraith, 1977 \\
\hline
\end{tabular}

Next, the techniques are briefly discussed.

\subsubsection{Buffer-oriented techniques}

Zsidisin and Ellram (2003) state that companies continue to rely on buffers, despite the associated costs. The use of a buffer is a common approach in managing supply uncertainty, regardless of the level of the perceived supply risk. These buffers are additional resources, called slack resources by Galbraith (1977), and may contain time, inventories or capacity. A make-to-stock (MTS) company carries an inventory. Many MTS companies produce consumer products to forecast demand. Customer orders are filled from stock in order to produce short delivery lead times for standardized products. Product variability is predetermined and narrow. Manufacturing may take place in batches or in a line system, and the production volume for individual products-per-period is high. Required delivery speed and delivery reliability is high.

The type of uncertainty MTS companies face is demand variability. This can further be divided into quantity uncertainty and timing uncertainty (Vollman et al., 1997, p. 456). Flexibility against the fluctuations in demand is managed by the inventory. Therefore, the main challenge is to provide the right sized inventory to meet the forecasted future demand. Vonderembse and White (1998) state that one strategy in midterm planning is to produce in a constant manner and to use the inventory to absorb demand fluctuations. Companies that produce products with seasonal demand 
often follow this strategy. If the inventory is the source of flexibility, forecasts are very important and forecast accuracy needs to be measured.

Assemble-to-order (ATO) scheduling is used in companies where the number of end product configurations is high and where the products are made from basic components or subassemblies. The customer delivery time requirement is shorter than actual production time. The large number of possible configurations makes forecasting at an end-item level difficult and stocking of end items risky. An ATO company has to manage work-in-process inventories to reduce overall manufacturing lead time and not start final assembly until the customer order is received. The final assembly schedule is designed to hold off commitment to unique product configurations in order to be able to offer a wide range of product configurations. The main uncertainty in ATO, in addition to demand variability, is product mix. The main challenge lies in making accurate promise dates to customers. Flexibility against the fluctuations in demand is maintained through work-in-process inventories and capacity buffers.

Make-to-order (MTO) companies build products according to customer specifications when needed. MTO is used when there are a large number of possible configurations and when exact customer requirements cannot be forecast, which makes MTO a suitable strategy for customized products with a large product variety. Customers allow long delivery lead times; they are prepared to wait for the product. The backlog of customer orders may be long, even many months, and orders may not be specified when they are booked. The typical production batch size is low, often one. The order backlog forms a large part of the delivery time and is used to respond to demand fluctuations. The main source of flexibility is therefore delivery lead time. The type of uncertainty in MTO concerns product specifications after they have entered the system. Even though there may be customer orders with exact timing for some time in the future, there may still be a lot of uncertainty concerning these orders.

To ensure adequate buffers, planning must include decisions such as whether the company should have excess capacity and how easy capacity change should be (Vonderembse and White, 1988). If capacity changes are needed, they need to be defined in terms of whether they should take place in large steps or small increments and in which timescale. One example in maintaining excess capacity is to define how work-force size can be adjusted. The first varies the workforce size, which is followed by, for example, service companies, because service cannot be inventoried. The second strategy is to hold the work force constant, but vary its utilisation by overtime work or a shortened week. In this strategy, the hiring and layout costs associated with the first mentioned strategy are avoided. Overtime costs and a higher payroll are the disadvantages of this strategy. The third is to hold the workforce constant and to produce to stock.

\subsubsection{Managing supply risks}

Zsidisin and Ellram (2003) discuss managing supply risks, which they define as unplanned events that can negatively affect the firm's ability to serve its own customers. Common techniques to shield from these risks are inventory management and the use of multiple supplying sources. Another way is to eliminate the source of risk, by devising or negotiating the environment in order to eliminate the uncertainty. This group of techniques includes supplier certification, implementing quality 
management programs, developing target costing with suppliers and supplier development. These behaviour-based techniques are adopted when the perceived risk is at a high level.

A similar solution (Galbraith, 1977) states that an organisation has to try to modify its environment instead of modifying its own processes or organisation. The writer names mechanisms to reduce environmental uncertainty, by, for example, guaranteeing access to scarce raw material resources or by contracting or cooperation.

\subsection{Conclusions from the literature}

The connection between supply chain planning from a manufacturing company point of view is not widely studied in the literature. Solutions to provide flexibility and solutions to manage uncertainties, instead, are treated in many literature sources. The presented approaches do not, however, consider how each flexibility solution should be used and how they affect supply chain planning. It was also interesting to note that delivery time was not considered as a source of flexibility in the literature sources we investigated. An exception is Galbraith (1977), who treats time as one type of slack resource. Another notion is that information sharing has been largely suggested as a means with which to respond to supply chain uncertainties. However, it has been found that focusing on lead-time reduction would be a much more efficient strategy in many supply chain settings (De Treville et al., 2004).

We are interested in how companies create flexibility in variable environments with different uncertainties from a supply chain viewpoint. Two research questions are formulated based on literature findings: 1) What factors affect the choice of planning approach in manufacturing companies? 2) How is the source of flexibility connected to the planning approach?

\section{Methodology}

This research is explorative, which is an appropriate approach as few empirical studies on supply chain planning exist. An inductive case study approach according to the principles set out by Eisenhardt (1989) is employed. Research is designed as a multiple case study to chart and understand the situational factors that explain the chosen planning methods in each case and to seek similarities and differences between cases. The rationale for the selected methodology is the depth of data. The focus area is broad and a broad range of data on the phenomenon is required to cover the subject and to understand the situational factors. In this kind of situation, case study research is the richest way to collect and understand context data (Yin, 2003).

To understand the connection between supplier and customer involvement in the midterm planning processes and sources of supply chain flexibility, an explanatory framework was developed. To create this, an analysis of the flexibility sources used in each case is performed and explanatory factors researched. After this, an analysis of 
the planning integration stage is performed. Based on these results, we propose two basic company groups formed according to their respective planning approaches.

The number of cases in this study was purposively limited to allow a deeper analysis and understanding of each case. Originally, the sample size was planned to be between six and eight and to cover different manufacturing companies. Another goal was to discover the state of planning integration with customers and suppliers. Therefore, we wanted to have companies that acted as brand owners in their supply chain and that therefore should have an interest in planning future volumes and also, in one way or another, ensure availability from suppliers and a good service level to customers.

Cases were selected from the participants in a two-year research project concerning product life-cycle management and supply chain management. All the seven manufacturing companies from the project were invited to the study; one of these declined the invitation due to timetable problems. We therefore ended up including six cases in the study.

The final sample consists of a variety of types of companies offering a variety of types of products, as presented in Table 2. Two of the case companies produce groceries, which are delivered via retailers to consumers. Two of the companies offer durable goods for consumers, and two serve industry or company customers with long-lasting equipment.

Table 2. Description of the case companies.

\begin{tabular}{|c|c|c|c|c|}
\hline Case & Industry & Market area & $\begin{array}{l}\text { End customer } \\
\text { type }\end{array}$ & $\begin{array}{l}\text { Direct } \\
\text { customers }\end{array}$ \\
\hline 1 & $\begin{array}{l}\text { Meat products and } \\
\text { convenience foods }\end{array}$ & $\begin{array}{l}\text { Scandinavia, Baltic; } \\
\text { study concerns } \\
\text { Finland }\end{array}$ & Consumers & Retail chains \\
\hline 2 & Confectionery & $\begin{array}{l}\text { Scandinavia, Baltic, } \\
\text { Poland, Russia }\end{array}$ & Consumers & Retail chains \\
\hline 3 & $\begin{array}{l}\text { Sofas and other } \\
\text { padded furniture }\end{array}$ & Finland & Consumers & Retail chains \\
\hline 4 & $\begin{array}{l}\text { Valve solutions for } \\
\text { process industries }\end{array}$ & Global & Industry & Industry \\
\hline 5 & Consumer electronics & $\begin{array}{l}\text { Global, study } \\
\text { concerns Europe }\end{array}$ & Consumers & $\begin{array}{l}\text { Distributors, } \\
\text { retailers, } \\
\text { operators }\end{array}$ \\
\hline 6 & $\begin{array}{l}\text { Display refrigeration } \\
\text { equipment for retail } \\
\text { stores }\end{array}$ & $\begin{array}{l}\text { Scandinavia and } \\
\text { Europe }\end{array}$ & Retail outlets & Retail chains \\
\hline
\end{tabular}

Both quantitative data and qualitative data were collected from these cases. The main data collection method was that of structured interviews; these took place during the autumn of 2005. Data was also collected from annual reports of the companies (in 
five cases), from company web pages, other printed material from the companies and the research results from an earlier interview study on IT benefits (reported in Auramo et al., 2005). In addition, the researcher had attained study projects in two of the case companies; the results of those projects were partly used as source material.

A questionnaire form was formulated covering the following themes: 1) Basic information concerning the company, 2) Products and demand characteristics, 3) The supply chain structure and operational models, 4) Planning approach and planning process, 5) Planning collaboration with customers and suppliers, 6) Planning results and planning quality, 7) Differentiated planning. The questionnaire included closed, open-ended and rank-ordered questions. The questionnaire was piloted in one case company, after which it was revised and its structure clarified.

In each company, one or two interviews lasting $1.5-2.5$ hours were carried out. The questionnaire was sent to the case companies before each interview to allow the respondents to become acquainted with it beforehand. The discussions were recorded. In each interview, there were two to four respondents, and one or two interviewers. The interviewees were responsible for production, production planning, sales, customer relationships, forecasting and purchasing. In one company, one person filled the questionnaire assisted by five other experts instead of an interview. Afterwards, additional phone calls or e-mail inquiries were conducted if needed.

\section{Results}

\subsection{Features of the case companies}

Each case company is quite different in nature. In Table 3, the case companies are presented with respect to production master scheduling approaches, delivery time to customers and service level. Only one company produces $100 \%$ of its production to stock. The others manufacture or assemble at least half of their production according to customer orders.

Table 3. Production mode, customer delivery time and service level in case companies.

\begin{tabular}{|l|l|l|l|l|l|}
\hline Case & MTO\% & MTS \% & ATO\% & Delivery time & Service level \\
\hline 1 & 45 & 55 & & $48 \mathrm{~h}$ & Near $100 \%$ \\
\hline 2 & & 100 & & $4-48 \mathrm{~h}$ & Near $100 \%$ \\
\hline 3 & 50 & 50 & & MTO 3-5 wks, stock items < 1 week & $70-80 \%$ \\
\hline 4 & 40 & & 60 & $\begin{array}{l}3-5 \text { months, fixed assortment 2-12 } \\
\text { weeks }\end{array}$ & $75-85 \%$ \\
\hline 5 & 10 & & 90 & $1-7$ days & $84 \%$ \\
\hline 6 & & 15 & 85 & $4-6$ weeks, stock items 1-2 weeks & $>90 \%$ \\
\hline
\end{tabular}


In cases 1, 2 and 5, delivery speed is very fast. In the grocery companies, in cases 1 and 2, service level is high. In cases 3, 4, and 6, where delivery time is weeks or even months, the companies are not able to maintain an adequate service level; this might be as low as 70 per cent. It is interesting to note that there does not seem to be a clear connection between required delivery speed and the production master scheduling approaches used. The three companies whose delivery time is short, typically 1-2 days, manufacture in either MTO, MTS or ATO mode. Companies with long delivery times deliver both from inventory and from production. One example of fast operations is company number 5, which assembles or manufacturers to order in less than seven days.

Data concerning product quantities and demand characteristics is depicted in Table 4. The most rapid changes in product assortment concerns consumer products. In cases 4 and 6 , the challenge is in managing the huge number of different variants. In these cases, most products are produced or assembled to order.

Table 4. Product diversity, innovation rate and demand characteristics in the case companies.

\begin{tabular}{|l|l|l|l|l|}
\hline Case & $\begin{array}{l}\text { No. of } \\
\text { products }\end{array}$ & $\begin{array}{l}\text { Annual new product } \\
\text { introductions, } \\
\text { \% of products }\end{array}$ & $\begin{array}{l}\text { No. of } \\
\text { competing } \\
\text { products in the } \\
\text { market }\end{array}$ & Demand characteristics \\
\hline 1 & 750 & $3-4 \%$ & $4-5000$ & $\begin{array}{l}\text { Seasonal differences are big, } \\
\text { dependent on product type }\end{array}$ \\
\hline 2 & 400 & $5-7 \%$ & 1500 & Seasonal differences are big \\
\hline 3 & $\begin{array}{l}600 \text { (not all } \\
\text { variants } \\
\text { included) }\end{array}$ & $3-4 \%$ & $\begin{array}{l}\text { Many, especially } \\
\text { from low-cost } \\
\text { suppliers }\end{array}$ & $\begin{array}{l}\text { Extensive price campaigns, } \\
\text { also seasonal differences }\end{array}$ \\
\hline 4 & $\begin{array}{l}2500+ \\
\text { variants }= \\
4-50000\end{array}$ & All products customized & $\begin{array}{l}10 \text { competing } \\
\text { suppliers }\end{array}$ & $\begin{array}{l}\text { Demand is affected by } \\
\text { projects and may vary; on } \\
\text { product level, unpredictable }\end{array}$ \\
\hline 5 & 2500 & $10-20 \%$ & 1000 & $\begin{array}{l}\text { On product variant level, } \\
\text { unpredictable; } 15 \% \text { of sales } \\
\text { variable }\end{array}$ \\
\hline 6 & 5000 & $\begin{array}{l}\text { Majority of products } \\
\text { customized }\end{array}$ & $\begin{array}{l}10 \text { competing } \\
\text { suppliers }\end{array}$ & $\begin{array}{l}\text { Seasonal differences; on } \\
\text { product level, unpredictable }\end{array}$ \\
\hline
\end{tabular}

Demand characteristics differ in the case companies. In groceries, seasonal differences are significant and may depend on the product type. In addition, case companies 3 and 5, which serve consumers with durable goods, face seasonal demand, and campaigning in the industries they represent is extensive. 


\subsection{Modes of collaboration with customers and suppliers}

The level of collaborative planning was the subject of inquiry in the interviews. The question was formulated as 'Do you collaborate with customers/suppliers in the following planning tasks?' If the answer was Yes, the respondents were asked to define the wideness of collaboration as a share of sales or purchases or as the number of collaborative customers or suppliers. Based on these responses, the level of collaboration was estimated as presented in Figure 1.

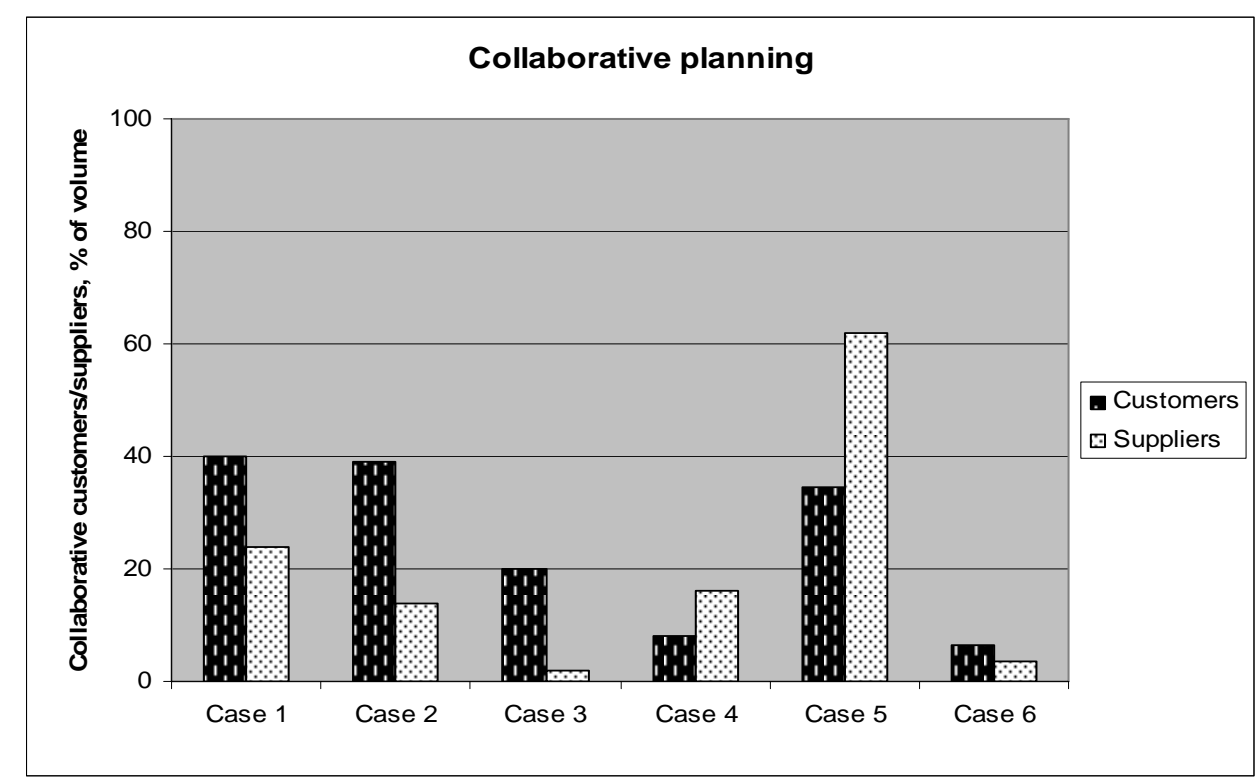

Figure 1. The level of collaborative planning with suppliers and customers in case companies, estimated figure based on interviews.

Those companies that serve customers via retailers collaborate actively with retail chains in assortment forming. Other important collaboration forms include campaign planning and seasonal planning, where planning horizons or planning frequency are the differentiating factors. The most important collaboration activity for these companies is demand forecasting, in relation to campaigns, seasons, and product introductions. Those companies that deliver to projects are actively participating in project planning.

Case company 5 serves its end customers through a multi-phased supply chain. In this company, customer collaboration is seen as an enabler in gaining access to demand data. A contrasting position is held by case company 3, which belongs to the same group of companies as its customers. It receives demand data from customers four times an hour.

The case companies can approximately be divided into two groups based on their relationship to suppliers. The first group relies on 'arms-length' relationships based on annual agreements, while the use of other collaboration forms is limited. Often, supply lead times may be long. This strategy is used also for cheap bulk raw materials that are buffered to cover the production needs of several products. 
The other group integrates suppliers into planning by maintaining weekly or monthly collaborative and information-sharing practices. This is used if product-specific variant components are needed and if delivery time to customers is short. The most important and expensive materials are thoroughly managed. Each case company has at least one vendor-managed inventory (VMI) relationship, more commonly with suppliers than with customers. For case company 5, VMI is the basic operation model with both customers and suppliers. If VMI is implemented with customers, it seems to be a strategic choice. It may offer access to demand information, or a way to level goods flow and to improve the balance between production and demand.

\section{The connection between flexibility and planning}

The flexibility sources adopted in case companies are shown in Figure 2. The bufferbased techniques of creating flexibility listed in Table 1 are the basis for the analysis. The identified sources of flexibility, production, inventory, and delivery time are treated from the viewpoint of a supply chain, and their location in the different parts of the supply chain is considered. Production is the main source of flexibility in Case companies 1 and 5. Both these companies are forced to respond to demand from production for two reasons: the product does not allow stocking and the customers require fast deliveries. In case 1 , the product is highly perishable with, at shortest, a shelf life of six days. In case 5, the products change fast, increasing the high risk of losses in the case of producing the wrong product and forcing the company to assemble to order within two or three days. Both these companies rely on an efficient forecasting process for sourcing materials.

In cases 1, 2 and 3, the inventory is used to offer flexibility. Case company 2 delivers all products from stock, whilst case company 3 delivers campaign products from stock. In all these cases, customers require fast deliveries, but the product can be stored, allowing the company to produce in batches and enjoy the economies of scale. Forecasts are crucial, and case companies 1 and 2 have formed an efficient forecasting process. Case company 3 receives campaign forecasts from retail chains, and produces additional batches based on point-of-sale demand data during the campaign.

Delivery time is the principal source of flexibility in cases 4 and 6 , and in sales campaigns in case 3. Order backlog forms a large part of delivery time. Procurement is based on the production plan, which, in turn, is based on orders. Typically, the fixed period in production is long. In project deliveries, the exact delivery time, as well as the product configuration, may change several times. 
Identified sources of flexibility

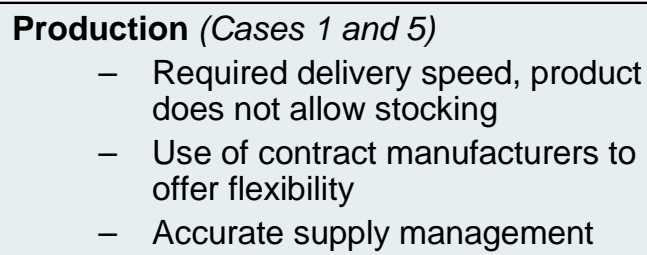

- Required delivery speed, product does not allow stocking

- Use of contract manufacturers to offer flexibility

- Accurate supply management

\section{Explanatory factors}

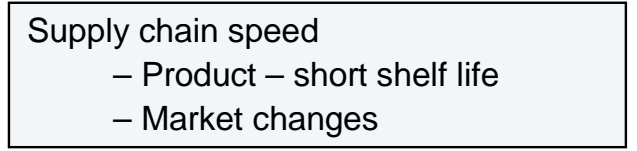

Customer delivery speed requirement The product allows stocking Production economics requires large production batches

Customer is ready to wait for the product Customization

Project deliveries

- Supplier integration level low

- Long fixed production planning period

Figure 2. Sources of flexibility in cases.

The three identified buffering solutions to the problem of offering flexibility, i.e. production, inventory and delivery time, are positioned in the supply chain as shown in Figure 3. We combine these into the level of collaborative planning, as is presented in Figure 1. When we locate the six case companies in the matrix according to the source of flexibility and the use of integrated planning, we observe that those companies that collaborate most are answering to customer requirements from production or inventory. Those companies that use inventory to provide flexibility are located at the middle level of integration, except case company 3 , which is at a low level. In those companies where delivery time is flexible, the planning process seems to be integrated to a lesser degree. 


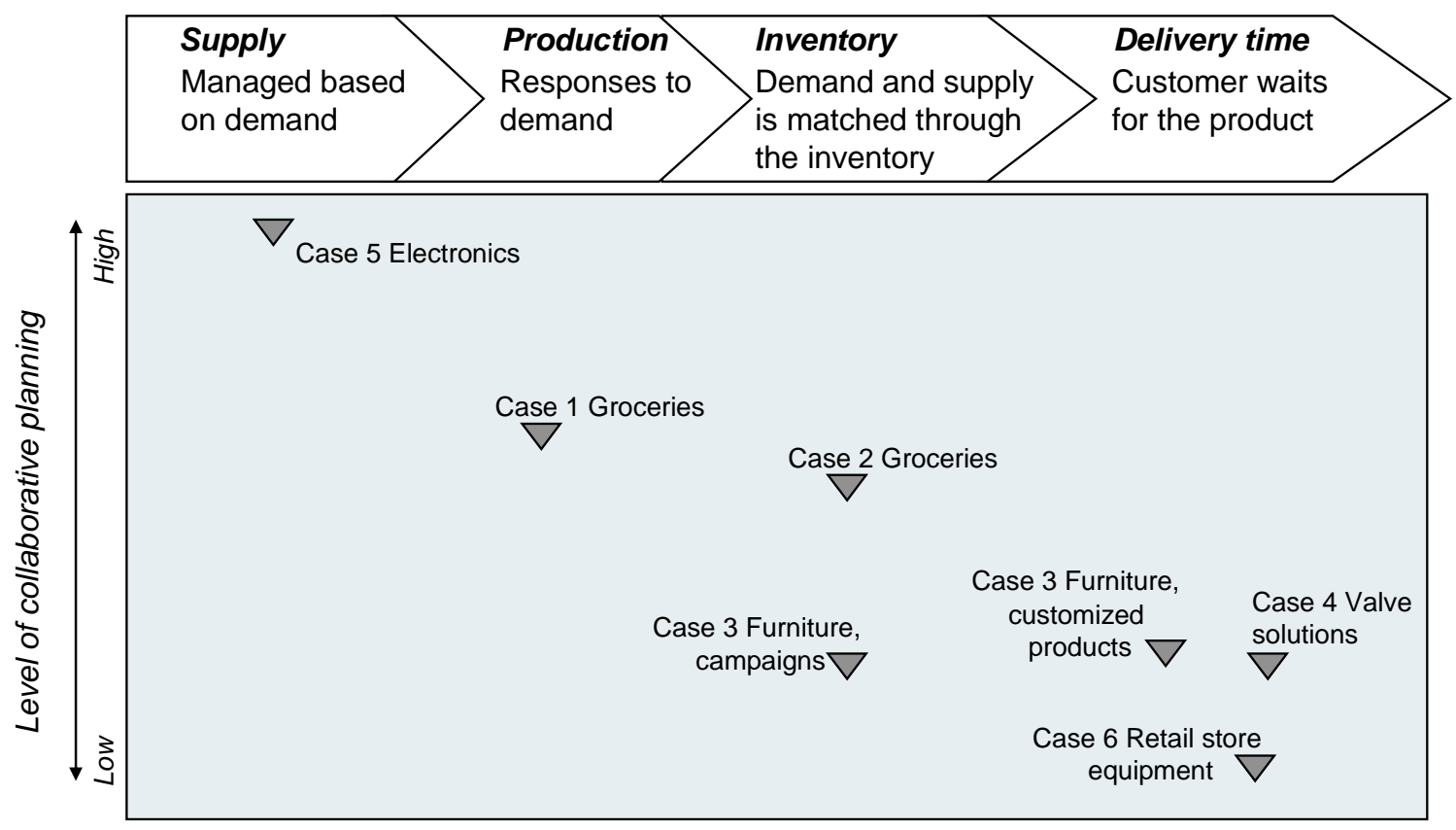

Figure 3. Sources of flexibility and the level of collaborative planning in the case companies.

Two types of companies can be identified according to their planning approach. The first type focuses on forecasts, while the other group relies on order-driven planning. These are differentiated on the basis of product characteristics, required delivery speed, flexibility source and supplier management practices (Table 5).

Table 5. Characteristics of the two planning approaches.

\begin{tabular}{|l|l|l|}
\hline & $\begin{array}{l}\text { Group 1 } \\
\text { Forecast-focused planning }\end{array}$ & $\begin{array}{l}\text { Group 2 } \\
\text { Order-focused planning }\end{array}$ \\
\hline $\begin{array}{l}\text { Delivery time to } \\
\text { customers }\end{array}$ & $4 \mathrm{~h}-7$ days & 2 wks - 6 months \\
\hline Product change rate & $4-20 \%$ & $0-3 \%$ \\
\hline Product type & Standard & Customized \\
\hline Source of flexibility & Production, inventory & Delivery time \\
\hline $\begin{array}{l}\text { Balancing demand and } \\
\text { supply }\end{array}$ & $\begin{array}{l}\text { In production plan or in a } \\
\text { separate balancing process }\end{array}$ & $\begin{array}{l}\text { In defining customer delivery } \\
\text { time }\end{array}$ \\
\hline The most important plan & Demand forecast or sales plan & Production plan \\
\hline $\begin{array}{l}\text { The most important } \\
\text { information source }\end{array}$ & $\begin{array}{l}\text { Historical sales data, demand } \\
\text { when available }\end{array}$ & Orders, order backlog \\
\hline
\end{tabular}


Companies that belong to group 1 deliver standard products at a high speed to customers. Product change rate is high, with up to $20 \%$ of products changing annually. These companies may operate in MTO, MTS or ATO mode. Flexibility is created in upstream phases of the supply chain, in manufacturing phases or by maintaining a finished goods inventory. Suppliers are integrated in the planning process to ensure raw material availability in production. The most important plan is the demand forecast or sales plan, both of which are based on historical data, and also demand data if available. These companies have created planning processes with process owners and a specialised IT system. A lot of resources are used in planning; in addition to system resources, the organisation employs planning specialists. Planning results are shared with suppliers.

The second group is formed of order-driven companies, whose delivery time to customers varies from a couple of weeks to several months. They produce customised products in ATO or MTO mode and are capable of offering a wide variety of different configurations of the product. Their most important plan is a production plan made from customer orders. Customer demand, production capacity or supply constraints are matched in a separate process where delivery time is defined. All three companies belonging to this group agree on volumes and availability requirements in annual agreements, after which the suppliers are expected to deliver ordered quantities in the promised delivery time. To ensure availability and flexibility in their own production, the companies keep a buffer on bulk raw materials. Because product configurations change, these companies are not able to benefit from multiple VMI relationships or from regularly shared information on future volumes with suppliers.

One further notion relating to the quality of plans is justified. The companies were asked to name their three most important company goals, and to estimate how well their current planning process supports reaching these goals in a range from 1 to 5 ( $1=$ planning process supports well reaching the goal, $5=$ planning process does not support reaching the goal). When considering the estimates the interviewees gave with regard to the success of their planning process, the forecast-driven companies did better in their planning (average 2.0) than order-driven companies (average 3.1). Also, in the internal quality of planning processes, the forecast-driven companies formed the top trio.

\section{Discussion}

De Treville et al. (2004) treat lead times in relation to access to demand information and propose that manufacturing lead time defines which activities companies should develop: if manufacturers cannot respond to demand due to long lead times, they should focus on planning and forecasting processes. Manufacturers with short lead times should concentrate their efforts on the transfer of actual demand information.

For our case manufacturers 3, 4 and 6, relative supply lead time is short, meaning that they access demand information (orders) before they have to begin manufacturing. However, their actual delivery time to customers is long and often variable, and they are aiming to utilise production capacity efficiently. Planning is infrequent and the planning horizon is long: a fixed period in production planning may be one month or 
more. Main plans are created on an annual basis: budget (case 4) or sales plan (case 6 ), and purchasing quantities are given to suppliers on an annual or quarterly basis. Therefore, we agree with de Treville et al.'s proposition that these companies should focus their planning on more-accurate and fast supply management. Instead, their proposition focusing on the quick transfer of demand information is irrelevant for these suppliers with a delivery lead time of several months.

In cases 1, 2 and 5, relative supply lead time is long, meaning that the companies access demand data after production has started. A sales plan or demand forecast is the most important plan, and these companies are focusing on developing planning and forecasting processes to support end-to-end planning. These companies use a lot of resources in planning, which typically takes place on a weekly or monthly basis. Collaboration is not limited to customer collaboration, but reaches suppliers also; case company 5 delivers plans to suppliers on a daily, weekly and monthly basis, and case company 2, weekly. These companies have focused both on supply and demand integration, which is in line with de Treville et al's proposition.

In those companies where delivery speed is not required and where delivery time is flexible, orders are used to manage the whole procurement and production process. These companies use fewer planning resources and do more infrequent planning than forecast-focused companies.

This result also has further implications. We may state that companies operating in industries where competition or the product innovation rate does not require a direct response to demand can still enjoy the benefits of long delivery times. If fast deliveries are required, the companies have to invest in collaboration and integrated planning to survive the competition.

\section{Conclusions}

In this study, the supply chain planning approaches taken by manufacturing companies were investigated using an interview study. Three conclusions can be drawn from the analyses.

First, an important factor in determining the planning approach was found to be the delivery speed of the chain. The results indicate that companies, which are required to deliver products to customers at a high speed are also required to develop efficient forecasting processes to manage the demand uncertainty. If lengthy delivery times are permitted, then the actual orders can be used as input data for planning for future volume. This result somewhat diverges from the definitions of master scheduling approaches, because we propose that companies operating in ATO and MTO modes need to rely on forecasting if very fast deliveries are required.

Second, the results indicated a connection between planning approach and supply chain flexibility. If the principal source of flexibility is located in the upstream phases, in production or suppliers, the company is also required to create integrated planning and information-sharing practices with customers and suppliers. Our study revealed that focusing only on the quick transfer of demand information or a more reactive 
planning process is irrelevant for manufacturing companies with a long delivery time, as the physical process is not able to respond to frequent plan changes.

The third conclusion is that supply chain planning practices are fragmented in companies and end-to-end planning is rarely the case. This finding has been discussed in the literature, in Makatsoris and Chang (2004), for example. Furthermore, planning does not always target the most important company goals. According to the results of this study, forecast focused planning provided better support for reaching company goals than order-based planning.

The number of cases was limited in this study to allow a deeper understanding of each case. The case companies were very different in nature. Although it was interesting to notice similar behaviour in both planning and supply management in various types of companies, it was also very challenging to compare, say, manufacturers of projecttype goods for industry and producers of consumer goods. If the cases presented had been of one industry or customer group, a richer analysis of industry-specific features would have been possible.

Further research could be devoted to end-to-end supply chain planning, for example, in the form of best practice case studies. The state of supply chain planning can be further investigated by more case studies. A comparison of planning processes in various industry sectors needs more cases in each sector. Furthermore, empirical studies on the connection between uncertainty and planning would be interesting, because planning, or control systems, as they are called by Mason-Jones and Towill (1998), is one cause of uncertainty in supply chains.

\section{References}

Auramo, J., Inkiläinen A., Kauremaa, J., Kemppainen K., Kärkkäinen M., Laukkanen S., Sarpola, S., and Tanskanen K., 2005. The roles of information technology in supply chain management. 17th Annual NOFOMA Conference, Copenhagen, Denmark, June 9.-10.

Byrne, P.J. and Heavey, C., 2006. The impact of information sharing and forecasting in capacitated industrial supply chains: A case study. The International Journal of Production Economics, 103 (1), 420-437.

Childerhouse, P., Aitken, J. and Towill, D. R., 2002. Analysis and design of focused demand chains. Journal of Operations Management, 20 (6), 675-689.

Childerhouse, P. and Towill, D. R., 2004. Reducing uncertainty in European supply chains. Journal of Manufacturing and Technology Management, 15 (7), 585-597.

Croom, S., Romano P. and Giannakis M., 2000. Supply chain management: Analytical framework for critical literature review. European Journal of Purchasing and Supply Management, 6 (1), 67-83.

Eisenhardt, K.M., 1989. Building theories from case study research. Academy of Management Review, 14 (4), 532-550.

Galbraith, Jay R., 1977. Organization Design. Reading Massachusetts: Addison Wesley Publishing Company. 
Gupta, A. and Maranas, C.D., 2003. Managing demand uncertainty in supply chain planning. Computers \& Chemical Engineering, 27 (8-9), 1219-1227.

Hoover, W. E., Eloranta E., Holmström, J. and Huttunen, K., 2001. Managing the Demand-Supply Chain: Value innovations for Customer Satisfaction. New York: John Wiley \& Sons, Inc.

Jordan, M.S., 2003. Pulling widgets into lean success. Industrial Engineer, 35 (3), 34 39.

Kreipl, S. and Pinedo, M., 2004. Planning and scheduling in supply chains: Overview on issues in practice. Production and Operations Management, 13 (1), 77-92.

Makatsoris, H.C. and Chang, Y.S., 2004. Design of a demand-driven collaborative supply-chain planning and fulfillment system for distributed enterprises. Production Planning \& Control, 15 (3), 256-269.

Mason-Jones, R. and Towill, D., 1998. Shrinking the supply chain circle. IOM Control magazine, 24 (7), 17-23.

De Treville, S., Shapiro, R. D. and Hameri A., 2004. From supply chain to demand chain: the role of lead time reduction in improving demand chain performance. Journal of Operations Management, 21 (6), 613-627.

Van der Vorst, J., and Beulens, A., 2002. Identifying sources of uncertainty to generate supply chain redesign strategies. International Journal of Physical Distribution \& Logistics Management, 32 (6), 409-430.

Stadtler, H., 2005. Supply chain management and advanced planning - basics, overview and challenges. European Journal of Operational Research, 163 (3), 575588.

Towill, D.R., Childerhouse, P. and Disney, S.M., 2002. Integrating the automotive supply chain: where are we now? International Journal of Physical Distribution \& Logistics Management, 32 (2), 79-95.

Vitasek, K.L., Manrodt, K.B. and Kelly, M., 2003. Solving the supply demand mismatch. Supply Chain Management Review, 7 (5), 58-62.

Vollman, T. E., Berry W. L. and Whybark, D. C., 1997. Manufacturing Planning and Control Systems. Fourth Edition. Irwin: McGraw-Hill.

Vonderembse, M. A. and White, G. P., 1988. Operations Management Concepts, Methods, and Strategies. St. Paul: West Publishing Company.

Yin, R. K., 2003. Case Study research, Design and methods. Thousand Oaks: SAGE Publications.

Zsidisin, G. A. and Ellram, L. M., 2003. The agency theory investigation of supply risk management. Journal of Supply Chain Management, 39 (3), 15-27. 